Rev. Pawet Bielecki

The John Paul II Catholic University of Lublin

DOI: $10.15290 /$ rtk.2021.20.11

iD $0000-0002-6354-6292$

\title{
The Christian Attitude Toward Physical Death Based on Gregory the Great's Homilies on the Gospels
}

Man is the only earthly creature who is aware of himself and of the inevitability of his death. Death, as a mystery and inescapable reality, has always been the subject of reflection and research. Popes have also discussed this issue in their teaching.

The aim of the article is to present human attitudes toward death in Gregory the Great's homilies from the fifth and sixth centuries. A textual analysis of these homilies reveals that man should prepare himself for death in such a way that death arouses not fear, but rather joyful entrustment to God. Gregory's homilies also convey that the decisions that a person makes throughout his lifetime have a powerful impact on the moment of his death. Pope Gregory demonstrates the interdependence of the free decision that man makes at the moment of death and the gift of eternal life with God. The pope proclaims that if someone lives a sinful life, then evil spirits will fight for his soul at the moment of his death. Therefore, it is of utmost importance to put one's life in order before death and to be safeguarded by the prayer of the community of the Church at the moment of death.

Key words: death, dying, Gregory the Great, fear of death, preparation for death.

Because death is a universal experience, man is generally aware of the fact that every person dies. Death is the natural consequence of sinful human nature. "Man is also the only creature in the world that is aware of his death and, therefore, can determine his attitude toward it. Man can either ignore death, or he can anticipate it; he can ascribe a certain meaning to death, or he can reflect metaphysically 
on his eternal future." Man has reflected on the reality of death since the dawn of time. In the ancient world, depending on the culture and community, death was connected to different beliefs that involved various rites. ${ }^{2}$ Many philosophers discussed this subject. The Holy Scripture presents man's struggle with death through the example of the Chosen People, who God created and led out of the land of Egypt. Death is not proper to man; it is the result of sin. This understanding of death serves as the foundation of early Christian eschatology that the Fathers of the Church discussed in their writings. Gregory the Great (540-604) $)^{3}$ is one such father, and he offers a variety of thoughts on death, especially in his Homilies on the Gospels. This article explores the main ideas about death that Gregory the Great presents in his homilies. He spoke of death as a great inscrutable mystery that man must face in order to arrive at the proper attitude toward it. His emphasis on preparing to die well is timeless.

Patrology

\section{Fear and the Witness of the Living}

With every passing hour of his life man ages and his death approaches. However, not every person is aware of this reality or accepts it. Awareness or ignorance of death is due to many aspects of human existence. Faith is one such aspect. A believer-a Christian-who anticipates eternal life and resurrection after death considers death simply one stage of life. Gregory the Great expresses such an attitude in his teaching, which leads to certain assumptions in the light of this unavoidable reality. A Christian can die peacefully in God because his faith makes him certain of eternal life. ${ }^{4}$ In this way, his death becomes both a witness and a lesson for those who witness it. However, not all people who have faith are certain of their eternal life. The two most common ways that people respond when they are confronted with the

1 B. Mielec, "Śmierć," in Encyklopedia Bioetyki, ed. A. Muszala (Radom: 2009), 581-582.

2 See C. Zuccaro, Teologia śmierci, trans. K. Stopa (Kraków: 2004), 9.

3 See M. Dal Santo, "Gregory the Great, the Empire and the Emperor", in: A Companion to Gregory the Great, ed. B. Neil, M. Dal Santo (Leiden: 2013), 57-81.

4 See John PaulII, Redemptor Hominis [EncyclicalLetter], sec.10, accessed October 20,2021, https://www.vatican.va/content/john-paul-ii/en/encyclicals/documents/ hf_jp-ii_enc_04031979_redemptor-hominis.html; M. Tarnowski, “Człowiek wobec śmierci," W drodze 123, no.11 (1983): 88; Z. J. Kijas, "Najważniejsze jest życie," in Brama śmierci. Pytania o sprawy ostateczne, ed. J. L. Franczyk (Kraków: 2007), 55. 
inevitability of death is to push it out of sight or mind, ${ }^{5}$ on the one hand, or to make a public spectacle of it, which evokes strong emotions as an antidote to the boredom of everyday existence, on the other. ${ }^{6}$ Pope Gregory noticed these different attitudes, and he discussed them. He stated, "If, indeed, the death of the righteous is a help to the good ones, it bears witness against the wicked, so that even that which serves to bring the elect to good so that they live, removes all excuses from the wicked when they perish." The quality of a person's life and his attitude toward God explain the broad range of attitudes that people have toward death. For those who live righteously on earth, their death is so good that it is a witness to others and an example for them to follow. The teaching of Gregory the Great clearly indicates that the person who spends his life preparing for death experiences it calmly or even anticipates it with hope. ${ }^{8}$ The opposite, however, is true of the sinner who never listens to God's admonitions; Gregory indicates that such a person should fear death. ${ }^{9}$ Those who do not believe in God Patrology and who live perverse lives approach death with dread, since they will be damned. In one homily, Pope Gregory recalls Jesus' parable about the talents, and he summons people to live good active lives, to prepare for a holy death, and to examine their consciences based on their entire life. ${ }^{10} \mathrm{He}$ then says,

The Lord comes when he approaches to judge; he knocks on the door when he warns us of the proximity of death by the attacks of an illness. We open it immediately if we welcome it with love. We do not want to

$5 \quad$ Man's attitude toward death changes with time and circumstances. See J. Jarco, "Współczesna problematyka śmierci," Życie i myśl 24, no. 10 (1974): 41-42.

$6 \quad$ See A. Nichols, Myśl Benedykta M. Wprowadzenie do myśli teologicznej Josepha Ratzingera, trans. D. Chabrajska (Kraków: 2005), 226; see M. Tarnowski, "Człowiek wobec śmierci," 87-88.

7 Gregory the Great, Homily 35, Homilies on the Gospels, accessed October 27, 2021, https://sites.google.com/site/aquinasstudybible/home/luke-commentary/ gregory-the-great-homily-35-on-the-gospels.

8 See Gregory the Great, Homily 13, Homilies on the Gospels, accessed October 27,2021,https://sites.google.com/site/aquinasstudybible/home/luke-commentary/ gregory-the-great-homily-13-on-the-gospels.

9 See Gregory the Great, Homily 38, Homilies on the Gospels, accessed October 27, 2021, https://sites.google.com/site/aquinasstudybible/home/ matthew-commentary/gregory-the-great-homily-38-on-the-gospels.

10 See R. Buliński, Program pracy duszpasterskiej papieża Grzegorza Wielkiego $w$ świetle ekshortacji pastoralnych zawartych w „XL Homiliarum in Evangelia” (Pelpin: 2008), 27-34. 
open to the Judge who knocks, if we are afraid of dying and we dread to see the Judge that we remember to have despised. ${ }^{11}$

According to the pope, contempt for God and the indifference to His will that results from it in one's present life cause a person to fear death and God's justice at the hour of death: "It is necessary to consider what terror will accompany the hour of our death, what a trembling of mind, what a memory of all our bad actions! It will be well forgotten, then, happiness passed! But what fear, what apprehension before the Judge!"12 While the teaching of the Second Vatican Council presents this idea and acknowledges fear of death, the conciliar documents claim that anxiety in the face of death is a natural manifestation of man's vocation to live: "Not only is man tormented by pain and by the advancing deterioration of his body, but even more so by a dread of perpetual extinction. He rightly follows the intuition of his heart when he abhors and repudiates the utter ruin and total disappearance Patrology of his own person." 13 Cardinal Ratzinger also recalled this thought of Gregory the Great when asserting, "if the mystery of life is identical to the mystery of love, it is also connected with all that happens after death."14

Saint Gregory the Great frequently mentions that man usually begins to think about his sins and the mistakes that he made during his life when he must confront death. Only then, according to Gregory, does a person begin to prepare for death: "Let a sickness seize us, let the symptoms of this sickness announce a near death to us, and seek an extension of life to mourn our sins; but this delay, which we then ask with a very ardent desire, we enjoy, at this moment, without making any case." 15 It is careless for an individual to avoid thinking about

11 Gregory the Great, Homily 13.

12 Gregory the Great, Homily 39, Homilies on the Gospels, accessed October 27, 2021, https://sites.google.com/site/aquinasstudybible/home/luke-commentary/ gregory-the-great-homily-39-on-the-gospels.

13 Second Vatican Council, Gaudium et Spes [Pastoral Constitution on the Church in the Modern World], sec. 18, accessed October 20, 2021, https://www.vatican. va/archive/hist_councils/ii_vatican_council/documents/vat-ii_const_19651207_ gaudium-et-spes_en.html; see W. Półtawska, "Katecheza o śmierci," Ateneum Kapłańskie 430, no. 2 (1980): 211.

14 J. Ratzinger, Stużyć prawdzie. Myśli na każdy dzień, 42; see B. Chyrowicz, "Chorzy na śmierć," Znak 9 (2000): 60.

15 Gregory the Great, Homily 12, Homilies on the Gospels, accessed October 27, 2021, https://sites.google.com/site/aquinasstudybible/home/matthew-commentary/gregory-the-great-homily-12-on-the-gospels; S. Kowalczyk, "Rozumienie 
death. ${ }^{16}$ Those who believe must also reject the desire to die suddenly, since death is the most important moment of life when a person matures and readies himself for real life-eternal life. Every attempt to penetrate the reality of death reveals the mystery of life. Gregory the Great emphasizes this idea when stating, "The Lord comes when he approaches to judge; he knocks on the door when he warns us of the proximity of death by the attacks of an illness." 17 According to Pope Gregory, every sickness or suffering that man experiences is an expression of God's concern for his salvation. God speaks in this way in order to encourage man to sort out his life. Death is woven throughout man's life like the resurrection is woven throughout the life of Christ. Consequently, the fundamental goal of living righteously is to find the path that leads not to emptiness and absurdity, but to eternal life.

\section{The Need to Prepare for Death}

Every person will have to face death, regardless of who he is and what he possesses, says St. Gregory, "And while death awaits us all with certainty, do not trouble yourself to foresee the uncertain future of this ephemeral life. Do not be bothered by concern for the things of the earth." 18 It is necessary for man to prepare for the moment of death. The pope warns the faithful of the tragic consequences of living a careless life that can end at any moment. He indicates the negative consequences of such a life by recalling the Gospel parable of the thief who comes unexpectedly in the night:

...the thief pierces the house: indeed, when our soul sleeps instead of watching over itself, death, rising unexpectedly, breaks our house of flesh, and having found its master asleep, it kills it; and when our souls do not foresee the chastisements to come, death brings them to torment because of their ignorance. ${ }^{19}$

This torment can be understood in different ways. St. Gregory the Great probably saw it as eternal condemnation or as the inner anxiety and suffering that a person experiences at the very moment of death. It is, therefore, important to always be prepared. However,

śmierci w głównych kierunkach filozoficznych," Ateneum Kapłańskie 72, no. 1 (1980): 374. źródła niepokoju i nadziei,” Communio 26, no. 6 (2006): 89.

17 Gregory the Great, Homily 13.

18 Ibid.

19 Ibid. 
preparedness does not mean living in sadness and being depressed because death is approaching. Life should be joyful; it is filled with victories and defeats, struggles and rich experiences, including the death of different people. ${ }^{20}$ The man who lives his life in a good way is happy when he dies because he is going to meet God. He longs for eternal life and prepares for it.

Gregory the Great warned his listeners about death out of his concern that they die peacefully and enter into eternal life. He also speaks about God's great mercy for man, who He calls to conversion away from his sinful life through certain signs:

Almighty God is accustomed to visit every sinful soul in many ways. He visits her relentlessly by his commandments, sometimes by a trial, sometimes even by a miracle, so that she hears the truths she did not know, and - if still she remains full of pride and contempt - that she returns to God in the pain of compunction, or else, overcome by the benefits, that she blushes for the evil she has committed. ${ }^{21}$

St. Gregory's words are realistic. ${ }^{22}$ Any sickness is a potential cause to reevaluate one's life and validate it. Sickness is, therefore, a good opportunity to change one's sinful life and to prepare for the final meeting with God, the Just Judge. In this regard, St. Gregory recalls the example of a young man who lived a sinful life and who, because of his iniquity, suffered from a terrible disease: ${ }^{23}$

Behold, a young debauched man saw at his death the demon he had served during his life; and this vision, far from making him lose his life, allowed him to know him whose slave he had made, that he might resist him, and that if he resisted, he would triumph over them. He, who before possessed him without seeing him, was finally given the

${ }_{20} \quad$ See L. Knabit, Najważniejszy dzień mojego życia. Refleksje o życiu i śmierci (Kraków: eSPe, 2007), 64.

$21 \quad$ Gregory the Great, Homily 39.

22 J. Pleskaczyński confirms that this still holds true. Based on his numerous experiences and conversations as a hospital chaplain, he states that patients, especially those in the intensive care unit, often thoroughly reflect on their lives. They frequently discuss their need to change their life radically. They say things like, "Why are you in such a hurry, chaplain? I used to live in a hurry as well." Close contact with the sick reveals that these seemingly simple reflections convey much deeper insight. See J. Pleskaczyński, "Kryzys sensu życia w doświadczeniu choroby i śmierci," Życie Duchowe 3, no. 5 (1996): 25-39.

23 Gregory the Great considers illness a warning of approaching death: A man is sick, and then he dies. See. Gregory the Great, Homily 13. 
opportunity to see him, so that he would no longer be possessed by him. ${ }^{24}$

God's mercy is so great that He gives man the chance to cling to Him and to choose Him even in man's very moment of agony. A person who encounters death and survives often changes his life and conduct. Conversion, however, which is a gift from God, is not just a formal declaration or simply an emotion. Conversion must be manifested in the ecclesial and sacramental rejection of sin and in choosing God. The First Person of the Holy Trinity then enters into the history of man's life and seeks his good in every possible way. God the Father wants to prepare man for death and warns him of any possible threats to his salvation.

\section{The Battle Between Good and Evil}

When describing the moment of death, Pope Gregory the Great recalls the ongoing battle between good and evil and writes about the ultimate decision that man must make between God and condemnation. Gregory speaks about how God permits man to choose or reject Him through a free act of the will. The pope recalls the dragon that symbolizes the devil. Satan appears before the dying in order to take his soul to hell: "But because this soul has not recognized the time of its visitation, it is delivered at the end of its life to enemies whom it will be obliged, by a judgment of eternal damnation, to share forever society." ${ }^{25}$ At the moment of death, man begins a new and eternal life. At this point, he enters into a state of complete freedom and perfect consciousness. This is the final moment when man, who experiences such freedom and consciousness, is able to genuinely choose or reject Christ. ${ }^{26} \mathrm{He}$ makes a decision using his free, full, and perfect will, and this choice determines his eternal fate. ${ }^{27}$ Many scholars and believers

24 Gregory the Great, Homily 19, Homilies on the Gospels, accessed October 27, 2021, https://sites.google.com/site/aquinasstudybible/home/matthew-commentary/ gregory-the-great-homily-19-of-the-gospels.

Gregory the Great, Homily 39.

26 Contemporary theology also reflects Gregory the Great's thought as the basis for its theology on death. For example, when drawing from Karl Rahner's theology of death, L. Boros develops it further and claims that man is given the possibility to choose Jesus at the moment of his death, and he can be saved regardless of how he behaved throughout his life just like the impenitent thief who was crucified next to Jesus. See L. Boros, Mysterium mortis (Warszawa: 1974), 58

27 This is called particular judgment. See L. Boros, Mysterium mortis, 58; C. Zuccaro, Teologiaśmierci, 70; R. Rogowski, "Śmierćjako sakrament życia,"Ateneum 
think that such a decision takes place; however, not everyone agrees on the particulars surrounding it. Some people claim that a good life guarantees a good death..$^{28}$ Those who support this line of thought also espouse preserving a certain balance between a good life and a good death. To this end, they treat life as a preparation for death and period when man makes less important decisions which will prepare and lead him to the final decision that he must make at the moment of death. ${ }^{29}$ Therefore, it is necessary to meditate peacefully on one's life, on the fact that it is passing, and on death.

Gregory the Great emphasizes the importance of the moment of death and considers it the most significant moment in human life. Death is also a trial and examination of how one lived one's earthly life. Saint Pope Gregory claims that, after the soul leaves the body, evil spirits that seek to enslave the soul and take it to hell will immediately surround it: ${ }^{30}$
Are there any greater enemies of the human soul than the evil spirits who come to besiege it as it goes out of her body, after having excited her by deceptive delights when she lived in the love of the flesh? They surround her with trenches, putting the faults she has committed under the eyes of her soul, and endeavoring to drag her into their common damnation, so that she is surprised at her last moments, while seeing by what enemies she is surrounded on all sides, yet she can not find a way to escape, because she can no longer do the good she refused to do when she could..$^{31}$

When preparing for death, every person should look retrospectively at his life. This entails the risk of losing everything that a person considered important. Such an examination may also evoke fear that everything for which one sacrificed his life and valued most during his life will become worthless. ${ }^{32}$ These types of things, which depend

Kapłańskie 72, no. 1(1980): 424; A. Nossol, “Historiozbawcze znaczenie śmierci," in Teologia bliższa życiu (Opole: 1984), 220-221.

See G. Moioli, “Doświadczenie chrześcijańskie a sens umierania,” trans. L. Balter, Communio 26, no. 6 (2006): 35.

When asked if he followed the theory that one makes a final decision at the moment of death, one contemporary theologian responded: "I think that death is the end... It is always possible to experience wonderful and radical conversions even at the moment of death, but this occurrence is rather miraculous." J. L. Franczyk, Brama śmierci. Pytania o sprawy ostateczne (Kraków: 2007), 67. Gregory the Great, Homily 39.

Ibid.

32 See J. Misiurek, "Ars moriendi - sztuka umierania," Homo meditans, no. 13 (1992): 243. 
on the person, should be worked out. In fact, this endeavor plays a significant and helpful role in the struggle that Pope Gregory the Great describes. Everything must be put in order, especially a person's interpersonal relationships with family and friends. This preparation process also necessitates disposing of one's possessions; amending for all the wrong that a person committed during his life; and reconciling with one's enemies. If it is possible, a person must bring to completion all of the tasks that he began during his lifetime. Hopefully, this will be possible and manageable with the help of eschatological hope, which is rooted in Jesus Christ and in His victory over death. ${ }^{33}$ During his lifetime, man should resolve to seek to love God in everything that he does. During his lifetime, which from an eternal perspective is but a brief time of trial, man can choose good or the evil, virtue or the vice, love or hatred. The battle between good and evil takes place at the moment of death. Choosing the good throughout one's life will make it easier ultimately to choose good at the final moment of death. ${ }^{34}$ While Patrology the aforementioned are only a few aspects of preparation for death to consider, they are the most significant because they will ensure that a person will approach the moment of death peacefully. ${ }^{35}$

When describing death, Pope Gregory recalls the attacks of evil spirits that take place. This battle occurs when man had not sorted out his sinful life before death. Pope Gregory states that enemies surround such a soul who cannot find escape. This means that the soul itself is unable to be victorious in the battle against Satan. For this reason, as St. Gregory points out, it is very important to live a good and moral life on earth. The saint also indicates the deceptive power of evil spirits:

So we must take care to meditate every day in tears with what fury and under what terrifying aspect the prince of this world will come, the day of our death, to claim what in us belongs to him, since he dared to address even to our God when he died in his flesh, to seek in him something [which belonged to him], without being able to find anything. ${ }^{36}$

See S. C. Kessler, “Gregory The Great,” in: Handbook of Patristic Exegesis, ed. D. J. Bingham (Leiden-Boston: 2006), 1345-1346.

See C. Kudroń, Do domu Ojca (Warszawa: 1983), 56. niepokoju i nadziei," Communio 26, no. 6 (2006): 87. 


\section{The Importance of the Community of the Church at the Moment of Death}

In His graciousness, God does not abandon man at such a decisive moment. Recalling an event that took place in one of the monasteries, Pope Gregory shows how the prayers of those who surround the dying person are important and helpful. Specifically, St. Gregory tells the story of the monk Theodore, who, thanks to the prayers of his fellow monks, was snatched from Satan's grasp:

However, during the plague epidemic that devoured a large part of the population of this city [of Rome], a groin tumor quickly dragged him to death. When he was about to die, the brothers came together to protect his end with their prayers. His body was already dead in his extremities, and he kept only a little vital heat in his chest. All the brothers began to pray for him all the more urgently as they saw him already leaving quickly. He suddenly screamed as loudly as he could, interrupting with great clamor the prayers of the brothers around him: "Get away! Withdraw! Here I have been fed to the dragon. Your presence alone prevents him from devouring me; my head is already in his mouth. Move away, so that he does not torture me more, but does what he has to do. If I have been given to him for food, why do I have to wait because of you?" Then the brothers began to say to him, "What are you talking about here, brother? Make the sign of the holy cross on you." He answered as he could: "I want to sign myself, but I can not, because the dragon crushes me." On hearing this, the brothers prostrated themselves on the ground, and all in tears, they began to pray with even more fervor for his deliverance. And suddenly the patient began to get better and to express his joy as much as he could, saying, "God be praised! The dragon who had received me in pasture is on the run. Your prayers chased him away, and he could not stay." 37

The evil spirit departed from the dying monk when he asked his brethren to pray for him and to beg God to forgive his sins. When Theodore's soul departed his body after he spent a few days praying for forgiveness for his sins, the dragon disappeared because Theodore had defeated it through his conversion of his heart.

The moment of death does not deprive man of the ability to choose God and to make the final decision that most frequently follows naturally from all of a person's previous decisions. If a person lived his earthly life for God and in God, then naturally he will choose God's mercy at the moment of death. ${ }^{38}$ The problem arises when man disre-

$37 \quad$ Gregory the Great, Homily 38.

See J. Misiurek, “Ars moriendi...,” 239; C. Kudroń, Do domu Ojca, 44. 
gards divine matters and lives a sinful life. St. George confirms that, in this case, an evil spirit will demand the sinful soul as its own property and take the soul into his kingdom of evil. ${ }^{39}$ The only hope for such a soul is to depend on God's mercy and on the prayers of family and the entire community of the Church. Once a person has died, he is no longer able to change his decision. He is not able to make a personal act in order to secure his salvation, even if he regrets his sins with all his heart. Only the living can help him through their persistent prayers. A person who has died is completely helpless and unable to determine his fate, so he is at the mercy of others. It is for this reason that St. Gregory the Great mentions the very significant role of prayer at the moment of death. According to Orthodox tradition, a sick or a dying person must not be left alone before or at the moment of death. His family and friends accompany him, read Holy Scripture to him, and pray for him. ${ }^{40}$ "A sick and helpless man in the condition of biological decay is unable to think or decide for himself; he has become indiffer- Patrology ent and distant from the world." ${ }^{41}$ In the Orthodox Church, friends and family consider accompanying the dying an important task and pray in order to help their loved one to reject the temptations and whisperings of the evil spirit and to choose God. Accompaniment can also be salutary for those present at the deathbed. When describing the moment of Abbot Steven's death, St. Gregory the Great says, "When the day of death came to force him out of his body, many came to recommend their souls to that holy soul who was leaving the world." 42

\section{Conclusion}

Studying the teaching of Pope St. Gregory the Great, which considers man's attitude toward death, leads one to the conclusion that Christians, like other men, adopt various attitudes toward death. According to this great saint, death remains a great mystery even though it accompanies man throughout his entire life and is present in his mind. Pope Gregory the Great discusses the issue of death in many of his homilies in an effort to quell his listeners' fear of death. He indicates that people fear death when their health deteriorates severely or when they must involuntarily accompany a dying person. One of the

$39 \quad$ See Gregory the Great, Homily 39.

40 See W. Hryniewicz, "Misterium śmierci w tradycji prawosławnej," Ateneum Kapłańskie 72, no. 1 (1980): 42.

41 C. Kudroń, Do domu Ojca, 44.

42 Gregory the Great, Homily 35. 
factors that influences man's attitude toward death is how he lived his life. Those who live good lives anticipate death with hope, while those who have done wrong are frightened of death, which evokes disgust. Faith-both practiced and lived out every day-greatly influences man's attitude toward death. Those who live a life full of evil, separated from God, and far from His commandments usually fear death. Since the quality of one's earthly life has such a significant effect on how one dies and the moment of one's death, Gregory the Great repeatedly points out the importance of preparing for death. The person who is not prepared to leave this world not only subjects himself to serious difficulties in the process of dying, but also and more importantly puts himself at risk of eternal damnation. Such an individual is not ready to leave all of his earthly possessions, which he had accumulated with great effort. The pope encourages his listeners to be alert and aware of signs through which God reminds man about life's transience, the

Patrology final judgment, and eternal life. These signs can manifest as warnings present in certain events, suffering, or miracles sent by God's grace. Such dialogue with God should help man have the proper attitude at the moment of death.

In his homilies, the pope also speaks about God's unfathomable mercy. God can forgive man even at the very moment of his death. However, it is man who may not be able to accept God's mercy. St. Gregory the Great teaches about the battle between good and evil that occurs at the moment of death. This struggle culminates in man's free decision, which is independent from worldly influence and the natural result of all of his previous life decisions. At the moment of death, man is able to either accept or reject God in a free and independent act of will for the very first time. If he sought God throughout his earthly life, then it will not be difficult for him to choose God at the moment of his death. However, if man lived a life far from God's will, then evil spirits will accompany him and attack him by reminding him of all of his sins and acts of wickedness in order to prompt him to choose eternal condemnation. Pope Gregory also adds that, regardless of how a person lived his life, God does everything in His power to help man in his struggle at the moment of death. In addition, the community of the Church, which prays for man's soul, can also help him. This earnest prayer on the part of the community can bring salvation to a person who had already given up and who no longer has the strength to make an act of repentance and regret the evil that he committed.

In conclusion, the Christian attitude toward death involves accepting God's will and the unavoidable circumstances of one's death. The 
factors that affect the moment of death include the life a person led and the decisions that he made in (or not in) accordance with God's will. It is important to live among a community of people who can assist one to accept God's mercy at the moment of death and in the struggle against evil.

\section{Bibliography}

1. Adamczyk, D. "Chrześcijańska postawa wobec mysterium mortis jako źródła niepokoju i nadziei." Communio 26, no. 6 (2006): 71-89.

2. Boros, L. Mysterium mortis. Translated by B. Białecki. Warszawa: 1974.

3. Buliński R., "Program pracy duszpasterskiej papieża Grzegorza Wielkiego w świetle ekshortacji pastoralnych zawartych.” In: „XL Homiliarum in Evangelia", Pelpin: 2008, 27-34.

4. Chyrowicz, B. "Chorzy na śmierć." Znak 9 (2000).

5. Dal Santo M., "Gregory the Great, the Empire and the Emperor." In: A Companion to Gregory the Great, ed. B. Neil, M. Dal Santo, Leiden: 2013, 57-81.

6. Franczyk, J. L. Brama śmierci. Pytania o sprawy ostateczne. Kraków: 2007.

7. Gregory the Great. Homilies on the Gospels. Accessed October 27, 2021. https://sites.google.com/site/aquinasstudybible/home/gregory-the-greathomiles-on-the-gospels.

8. Hryniewicz, W. "Misterium śmierci w tradycji prawosławnej." Ateneum Kaptańskie 72, no. 1 (1980): 39-50.

9. John Paul II. Redemptor Hominis [Encyclical Letter], sec. 10. Accessed October 20, 2021. https://www.vatican.va/content/john-paul-ii/en/encyclicals/documents/hf_jp-ii_enc_04031979_redemptor-hominis.html.

10. Jarco, J. "Współczesna problematyka śmierci." Życie i myśl 24, no. 10 (1974): 41-47.

11. Kessler S. C., "Gregory The Great." In: Handbook of Patristic Exegesis, ed. D. J. Bingham, Leiden-Boston: 2006, 1336-1368.

12. Kijas, Z. J. "Najważniejsze jest życie.” In Franczyk J. L., Brama śmierci. Pytania o sprawy ostateczne. Kraków: 2007.

13. Knabit, L. Najważniejszy dzień mojego życia. Refleksje o życiu i śmierci. Kraków: 2007.

14. Kowalczyk, S. "Rozumienie śmierci w głównych kierunkach filozoficznych." Ateneum Kaptańskie 72, no. 1 (1980): 367-381.

15. Kudroń, C. Do domu Ojca. Warszawa: 1983.

16. Mielec, B. "Śmierć." In Encyklopedia Bioetyki, edited by A. Muszala. Radom: 2009.

17. Misiurek, J. "Ars moriendi - sztuka umierania." In Homo meditans, no. 13, 231-244. Lublin: 1992, 231-244.

18. Moioli, G. „Doświadczenie chrześcijańskie a sens umierania,” translated by L. Balter, Communio 26, no. 6 (2006): 27-53.

19. Nichols, A. Myśl Benedykta M. Wprowadzenie do myśli teologicznej Josepha Ratzingera. Translated by D. Chabrajska. Kraków: 2005. 
20. Nossol, A. "Historiozbawcze znaczenie śmierci.” In Teologia bliższa $\dot{z} y c i u$, 215-222. Opole: 1984, 215-222.

21. Pleskaczyński, J. "Kryzys sensu życia w doświadczeniu choroby i śmierci." Życie Duchowe 3, no. 5 (1996): 25-39.

22. Półtawska, W. "Katecheza o śmierci." Ateneum Kapłańskie 430, no. 2 (1980): 208-217.

23. Ratzinger, J. Stużyć prawdzie. Myśli na każdy dzień. Poznań-WarszawaLublin: 1983.

24. Rogowski, R. "Śmierć jako sakrament życia.” Ateneum Kapłańskie 72, no. $1(1980)$.

25. Second Vatican Council. Gaudium et spes [Pastoral Constitution on the Church in the Modern World], sec. 18. Accessed October 20, 2021. https:// www.vatican.va/archive/hist_councils/ii_vatican_council/documents/vatii_const_19651207_gaudium-et-spes_en.html.

26. Tärnowški, M. "Człowiek wobec śmierci." W drodze 123, no. 11 (1983): 87-94.

27. Zuccaro, C. Teologia śmierci. Translated by K. Stopa. Kraków: 2004. 